\title{
The Ups and Downs of the Environmental Kuznets Curve
}

\author{
Arik Levinson \\ Georgetown University \\ Prepared for the UCF/CentER conference \\ on Environment, November 30-December 2, 2000 \\ Orlando, FL
}

\begin{abstract}
By now the observation that some pollutants appear to increase and then decrease with economic development has become a widely accepted stylized fact. This paper argues that the fundamental insight of the empirical literature is merely that pollution does not necessarily increase with economic growth, and that the fundamental insight of the theoretical literature is that the observed inverse-U-shaped pollution-income relationship is neither necessary nor sufficient for Pareto-efficient environmental policies. Furthermore, the inverse-U-shaped path is not unique to environmental phenomenon, and may exist wherever a desirable good generates an undesirable side-effect. Finally, all of these points can be made without most of the econometric or theoretical mechanics that fill this literature.
\end{abstract}

\section{Acknowledgments}

The author gratefully acknowledges financial support by the National Science Foundation, and research assistance from Esin Sile. 


\section{The Ups and Downs of the Environmental Kuznets Curve}

\section{Introduction}

Almost ten years ago, Grossman and Krueger (1991) and the World Bank (1992), publicized evidence that some measures of environmental quality appear to deteriorate with countries' economic growth at low levels of income per capita, and then to improve with economic growth at higher levels of income. Poor countries' environments get more polluted with economic growth, while rich countries' environments improve. Because this pattern of pollution and income bears superficial resemblance to the pattern of inequality and income documented by Kuznets (1955), the pollution-income relationship has been labeled an "environmental Kuznets curve."

Both Grossman and Krueger's paper, and the World Bank paper take the same strikingly simple approach. They regress average ambient levels of pollution on a polynomial in GDP per capita, across different countries and different time periods. They then plot the fitted values of pollution levels as a function of GDP per capita, and show that many of the graphs appear inverse-U-shaped, with peak pollution levels somewhere in the range of middle-income countries.

This observation, that pollution increases and then decreases with economic growth, has become a widely accepted truth, cited by op-ed pages and policy briefings world-wide. Simultaneously, it has sparked empirical and theoretical academic research. The empirical branch of the environmental Kuznets curve literature attempts to find similar patterns for additional pollutants, such as carbon, lead, hazardous waste, and indoor air pollution, and to test 
the sensitivity of the findings to functional form assumptions, specifications, time periods, countries, and additional control variables. The literature now includes papers with dynamic panel data models, fixed and random effects, splines, semi-parametric and non-parametric specifications, and includes controls for numerous country characteristics such as democratization, trade liberalization, and corruption. Some papers confirm inverse-U's with other pollutants, countries, and time periods. Others argue that the result is spurious, and is highly sensitive to functional form assumptions and specifications.

The theoretical branch of the environmental Kuznets curve literature has attempted to model the pollution-income relationship. Models range from simple statics to complex dynamic models with overlapping generations and endogenous policy determination. Some have welfare maximizing solutions that generate smooth inverse-U-shaped pollution-income paths, others rely on discrete jumps among multiple equilibria, while still others switch abruptly from constrained "corner solutions" to interior optima in a sort of "inverse-V-shaped" pollution-income path. Some even have multiple changes of direction and are "N-shaped," or "sideways-mirrored-Sshaped."

The thesis of this paper is that both branches of the literature have lost sight of the fundamental questions raised by the original observation, and have obscured those questions in a thicket of mathematics and econometrics. First, the fundamental empirical observation is that, as Grossman and Krueger (1995) note, there is "no evidence that environmental quality deteriorates steadily with economic growth." Demonstrating this point does not require sophisticated econometrics. All one needs to do is show that there are some countries and some pollutants for which a time series of pollution plotted against GDP per capita shows a downward trend. Pooled 
estimates with fixed effects or random effects, polynomials, lagged values of GDP, and multiple control variables distract from the fundamental empirical question: are there pollutants that have declined with economic growth for some countries? In what follows I demonstrate that the answer to this question is unambiguously yes. For the few industrialized countries with sufficiently long time series in the data set used by Grossman and Krueger, one can document steady declines in ambient levels of urban air pollution, concurrent with economic growth.

The second area in which the environmental Kuznets curve literature has lost sight of the environmental forest for the mathematical trees involves the theory. It seems to me that the fundamental theoretical question raised by Grossman and Krueger's observation is whether the inverse-U-shaped pattern has normative implications for policy. We would like to know, for example, whether the upward-sloping portion of the pollution-income path, which is eventually reversed, is sufficient evidence that poor countries are enacting bad policies and would benefit from international guidance in setting local pollution standards. Alternatively, some have claimed that the downward sloping portion of the curve is evidence that local pollution problems are somehow "self-correcting," and that the best environmental policy for developing nations is to grow wealthy as fast as possible.

These questions can be answered with the simplest of economic models, without dynamics, endogenous policies, or multiple equilibria. In what follows, I borrow from Andreoni and Levinson (2001) and show that an inverse-U-shaped pollution income path can be consistent with either Pareto-efficient policies, or sub-optimal behavior with market failures. In other words, an observed inverse-U-shaped pollution-income path is neither sufficient evidence that 
poor countries' policies are inefficient, nor sufficient evidence to justify laissez-faire pollution regulations.

Most economics papers begin with theory, and support that theory with econometric evidence. This literature has proceeded in the opposite direction: first developing an empirical observation about the world, and then attempting to supply appropriate theories. Accordingly, I will follow the unconventional pattern and begin with the empirical evidence.

\section{Empirical evidence for an Environmental Kuznets Curve}

Since Grossman and Krueger's paper, the empirical literature has multiplied. Table 1 briefly outlines some of that literature. The papers in Table 1 apply various approaches to a wide variety of environmental problems. The original Grossman and Krueger paper regressed ambient pollution on a cubic polynomial in GDP per capita and lagged values of GDP per capita, using a random effects specification, while the World Bank (Shafik and Bandyopadhyay, 1994) regressed those same pollutants on a quadratic in GDP per capita with fixed effects. Both found robust inverse-U-shaped relationships.

Since then, the literature has taken two directions. One tests the robustness of the early findings to functional form assumptions and specifications. Because this empirical literature is based on no underlying theory, it is particularly susceptible to such critiques. Harbaugh et al. (2000), for example, find that some of the original findings in this literature are changed dramatically by updates to the underlying data, and by the use of slightly different functional forms, and that confidence bands around the predicted pollution-income paths are wide enough to accommodate almost any pattern, inverse-U-shaped or otherwise. 
A second, and far larger, set of papers seeks to expand these early results to other pollutants, including carbon (Holtz-Eakin and Selden, 1995; Taskin and Zaim, 2000), lead (Hilton and Levinson, 1998), automobile emissions (Kahn, 1998), toxic waste (Wang et al., 1998; Millimet and Stengos, 1999; Arora and Cason, 1999), and indoor air pollution (Chaudhuri and Pfaff, 1998). This last is notable because indoor air pollution is arguably entirely internalized. If households make rational, fully-informed decisions, then there are no market failures associated with indoor air pollution, and the Chaudhuri and Pfaff result suggests that an inverse-U-shaped pollution-income path is consistent with Pareto-optimality.

By and large, the papers in this literature manage to find inverse-U-shaped patterns for most pollutants. The exceptions have reasonable explanations. Carbon emissions, for example, seem to increase at ever decreasing rates, but predicted peaks are far outside reasonable income levels. As a global pollutant involving cross-border externalities, no one country has sufficient incentive to regulate emissions. The free rider problem may simply be more troublesome with carbon than any other pollutant.

Some researchers find an "N-shaped" path relative to income -- increasing at low levels of income, decreasing at high levels, and then increasing again at even higher levels of national income. Grossman and Krueger dismiss the upper tail of this pattern as an artificial construct of the fact that they use a cubic functional form. The upper tail contains sparse data, and its shape is driven by the pattern of data at lower incomes. Millimet and Stengos, on the other hand, find a similar pattern with a semi-parametric specification, and so take the result seriously.

Finally, some pollutants appear only to decline with income, but this must by definition be a result of the data available. The researchers merely do not have data from earlier periods in 
which the pollution presumably increased, and only document the period of decline. In other words, in those cases documenting monotonic declines in pollution, the long-run pollutionincome path must be roughly inverse-U-shaped. Environmental quality that is improving must once have degraded. Or, to abuse the cliche, "what goes down, must once have gone up." Ironically, this last point may be the most important insight of the literature. If we assume that countries cannot improve their environments beyond some primitive natural state, then environmental problems are only of consequence in those cases where economic growth has at some point been associated with increasing pollution. The upward sloping portion of the environmental Kuznets curve, in other words, is really not of interest. What is interesting, and perhaps policy relevant, is whether pollution eventually stops increasing with economic growth and begins to decline. In other words, economists have long argued that pollution is not an inevitable consequence of economic growth, but without convincing evidence. Now it appears that for the first time we have long-term panel data describing various pollutants in different countries, and can back up that claim. The original papers in this literature (Grossman and Krueger, Shafik and Bandyopadhyay) began to make this point -- that pollution does not deterministically increase with growth -- but were side-tracked by their functional form specifications into searching for inverse-U shapes.

To make the point slightly differently, what we would like to know is whether in fact there is convincing evidence that some forms of pollution decline with economic growth for some countries. This, it turns out, is a far simpler point to make than predicting an entire inverse-U-shape pollution-income path. 


\section{Non-econometric evidence that pollution can decline with economic growth}

To make the point that pollution can decline with income per capita, all one needs do is plot pollution levels against GDP per capita for some sample pollutants and countries. As an example, consider $\mathrm{SO}_{2}$, the pollutant most frequently found to have an inverse-U-shaped pattern, and internationally the best-monitored pollutant.

The GDP per capita data come from Summers and Heston's (1991) Penn World Tables. Data on ambient pollution levels used by the World Bank and Grossman and Krueger in their original work were collected by the Global Environmental Monitoring System (GEMS), sponsored by the World Health Organization (WHO) and the United Nations. The EPA maintains these data in its Aerometric Information Retrieval System (AIRS). For $\mathrm{SO}_{2}$, the GEMS data contain 2401 annual observations from 285 monitoring stations in 102 cities in 45 countries, from 1971 to the present. Because the Summers and Heston data only extend to 1992, this analysis stops at that date.

Figure 1a depicts a cross-section of mean $\mathrm{SO}_{2}$ readings from each monitoring station in 1980, plotted against GDP per capita. The observations are stacked up because there are multiple readings from each country, each with a single value of GDP per capita in 1980. These are the numbers used to run the regressions plotted by Grossman and Krueger, and by the World Bank. By looking at figure 1a, one can see the difficulty inherent in discerning any particular pattern. The data are roughly consistent with an environmental Kuznets curve, with the highest pollution readings coming from middle income countries. However, middle-income countries also have monitoring stations with low $\mathrm{SO}_{2}$ readings, so one cannot draw immediate conclusions from this figure. 
Figure $1 \mathrm{~b}$ plots the average $\mathrm{SO}_{2}$ reading across all monitoring stations within a country, against GDP per capita. So by contrast to Figure 1a, Figure 1b has only one observation per country. One has to squint a little harder at this diagram to make the claim that cross-section evidence supports any particular decline in pollution levels at high incomes.

However, if the fundamental point to be made by this literature is that pollution does not inevitably increase with income, then cross-sectional evidence is irrelevant. Five of the studies reviewed in Table 1 contain only cross-sections of pollution and incomes at single points in time. While such evidence may suggest that richer countries are cleaner than middle-income countries, it does not necessarily show that richer countries have become cleaner over time. For that, we need time series evidence.

Most of the studies in Table 1 do use panels of data, but they typically pool time series and cross-section evidence. Grossman and Krueger, for example, estimate panel data models with random effects. The coefficients on GDP per capita are thus identified partly from crosssectional comparisons of countries within a given year, and partly from time series comparisons within given countries. Again, however, if the fundamental point to be made by this literature is that pollution does not deterministically increase with income, then all we need do is show some countries whose pollution levels have declined with economic growth.

Take airborne Sulfur pollution in the U.S., for example. Showing that a decline in pollution levels has occurred contemporaneously with economic growth is slightly more complicated than merely plotting average monitoring station readings against GDP per capita. That is because over time, countries have expanded the number of monitoring stations. If new 
stations are added in successively cleaner locales (the dirtiest places are targeted first), then the averages will display a spurious downward trend.

To avoid the bias inherent in the selection of monitoring station locale, in figure $2 \mathrm{I}$ have plotted average SO2 readings from the 22 monitoring stations in the U.S. that were continuously active from 1979 through 1992. As is clear from the picture, economic growth and environmental cleanup are not mutually exclusive. Though other countries have fewer monitoring stations and fewer years of continuous data, the same trends are notable among industrialized countries. ${ }^{1}$

In sum, aggregate panel data on pollution levels across countries over time are noisy, and patterns are difficult to discern in the raw data. A large variety of empirical specifications attempting to detect such patterns have, in the literature, yielded an equally large variety of predictions. Nevertheless, for some pollutants it is quite easy to document steady improvements in ambient air quality, concurrent with economic growth. This is consistent with the claim that economic growth does not necessarily degrade the environment.

Although initially no economic theory provided foundations for understanding these data, in the past 10 years that gap has begun to be filled.

\section{Theory}

To interpret the empirical observations outlined in Table 1, an equally diverse theoretical research has sprung up, each paper with its own normative implications. Several of these papers are summarized in Table 2. Perhaps the simplest, though least conclusive, interpretation of the

\footnotetext{
${ }^{1}$ See Greenstone (2001) for a more detailed analysis of these trends.
} 
empirics is that the inverse-U-shaped pollution-income path is merely the natural progression of economic development, from clean agrarian economies to polluting industrial economies to clean service economies (Arrow, et al., 1995). This interpretation is inconclusive because it has no normative or predictive power. Since we cannot say what the next phase of economic development will bring us, we cannot predict the future pollution-income path.

One troubling corollary to the "natural progression" theory is that the economic cleanup by rich nations may be facilitated by advanced economies exporting their pollution-intensive production processes to less-developed countries (Suri and Chapman, 1998). If so, then the economic improvement noted in industrialized countries will not be indefinitely replicable, as the world's poorest countries will never have even poorer countries to which they can export their pollution.

An alternative explanation with strong normative implications is in Jones and Manuelli (2000). They note that poor countries may not have the advanced institutions necessary for internalizing externalities. Their model consists of overlapping generations in which the younger generation sets pollution regulations. Depending on the collective decision-making institution, the pollution-income relationship can be an inverted-U, monotonically increasing, or even a "sideways-mirrored-S" (what others have called "N-shaped"). One normative implication of their paper is that poor countries' inability to self-regulate leads to inefficiently high pollution, and that international aid organizations could improve everybody's welfare by insisting on, or assisting with, regulatory standards and enforcement.

Still another set of models depicting inverse-U-shaped pollution-income paths relies on some constraint being relaxed at a threshold level of income. Stokey (1998), for example, 
describes a static model with a choice of production technologies with varying degrees of pollution. Her critical assumption is that below a threshold level of economic activity, only the dirtiest technology can be used. With economic growth, pollution increases linearly with income until the threshold is passed and cleaner technologies can be used. The resulting pollutionincome path is therefore inverse-V-shaped, with a sharp peak at the threshold income where cleaner technologies become available.

Similarly, Jaeger (1998) assumes that at low levels of pollution consumers' taste for clean air is satiated, and that the marginal benefit of additional environmental quality is zero. Consequently, with few firms and few individuals, the environmental resource constraint is nonbinding. More pollution does not result in lower utility. With economic growth represented by a growing population of individuals and polluting firms, once the satiation threshold of consumers' preferences is passed, depending on the parameters, growth may be accompanied by improved environmental quality. Jaeger's pollution-income relationship is also inverse-V-shaped, peaking when the optimum moves from a corner solution to an interior solution.

Finally, John and Pecchenino (1994) present an overlapping generations model in which environmental quality is a stock resource that degrades over time unless maintained by investment. An economy that begins at the corner solution of zero environmental investment will see its environmental quality decline with time and with economic growth until the point at which positive environmental investment is desired, when environmental quality will begin improving with economic growth. John and Pecchenino's pollution-income relationship also exhibits an inverse-V shape, peaking when the dynamic equilibrium switches from a corner solution of zero environmental investment to an interior optimum with positive investment. 
Each of these "constraint-relaxation" stories, or "threshold" stories, involves the conclusion that at low-levels of income, countries are somehow endowed with an excess of environmental quality. Stokey's producers would like to use an even more polluting technology, were one available. Since it is not, they use the dirtiest available technology and pollution increases steadily with production, until such time as they begin to value the environment and switch away from that dirtiest technology. Similarly, John and Pecchenino's citizens would like to trade environmental quality for other goods, but cannot, so they slowly degrade their environment with polluting production until they reach an income threshold beyond which they care about pollution and begin to invest in environmental quality.

The normative implication of these papers is just the opposite of the Jones and Manuelli paper. Here, low-income countries' degradation of their environments is efficient. In fact, if we could somehow relax the technology or endowment constraints in these models, they would get more polluted even faster.

The ultimate conclusion of the literature must be that, at least to date, there are no normative implications of the observed inverse-U. Some models generate inverse-U's that are Pareto-efficient, others generate inverse-U's that are market failures. Since inverse-U's can be generated with a variety of assumptions, and the normative implications depend on the assumptions, the observed inverse- $\mathrm{U}$ tells us nothing. The thesis of this paper is that we do not need most of the mechanics in the existing literature to come to that conclusion. To make that point, in the next section I summarize the results of a simple model that neatly generates both efficient and inefficient inverse-U-shaped pollution-income paths. 


\section{A one-person, one-good, one-factor, one-period model of the environmental Kuznets curve}

Consider the following Robinson Crusoe-style model, borrowed from Andreoni and Levinson (2001). Imagine Robinson Crusoe, alone on his island, picking coconuts for food. Each coconut generates one coconut shell, which Crusoe can either toss aside as unsightly litter, or dispose of properly in a dump. Crusoe gets utility from consumption of coconuts, $C$, and disutility from pollution, $P$ (coconut shell litter).

$$
U=U(C, P)
$$

where $U_{C}>0$ and $U_{P}<0$.

Suppose that Crusoe can dispose of his litter properly, but at the cost of foregone consumption. Pollution is then a function of consumption, $C$, and effort spent hauling coconuts to the dump, denoted $E$.

$$
P=P(C, E)
$$

where $P_{C}>0$ and $P_{E}<0$.

Finally, suppose Crusoe has an endowment, $M$, of time that can be spent on $C$ or $E$. For simplicity, normalize the relative costs of $C$ and $E$ to be 1 . So $C$ denotes one hour's worth of coconuts, and $E$ denotes one hour's worth of cleanup effort. The resource constraint is therefore simply $C+E=M$.

For example, consider a version of (1) and (2):

$$
\begin{gathered}
U=C-P \\
P=C-C^{\alpha} E^{\beta}
\end{gathered}
$$


Utility in (3) is additive and linear, and the marginal disutility of pollution is one. Pollution in (4) has two parts. The first term, $C$, is gross pollution before any abatement and is proportional to consumption. The second term of (4), $C^{\alpha} E^{\beta}$, represents abatement. So consumption in this model causes pollution one-for-one, but clean-up effort abates pollution with a standard concave production function.

The nice feature of this Robinson Crusoe model, with only one economic agent, is that without externalities, any private optimum by construction economically efficient. To solve for Crusoe's optimum consumption and pollution level, substitute (4) into (3) and maximize $C^{\alpha} E^{\beta}$ subject to $C+E=M$. Consumption and effort then have standard Cobb-Douglas solutions

$$
C^{*}=\frac{\alpha}{\alpha+\beta} M \quad \text { and } \quad E^{*}=\frac{\beta}{\alpha+\beta} M
$$

Substituting (5) into (4), the optimal quantity of pollution is then

$$
P^{*}(M)=\frac{\alpha}{\alpha+\beta} M-\left(\frac{\alpha}{\alpha+\beta}\right)^{\alpha}\left(\frac{\beta}{\alpha+\beta}\right)^{\beta} M^{\alpha+\beta} .
$$

Equation (6) represents optimal pollution as a function of Crusoe's endowment. If it is inverseU-shaped, it would be called an environmental Kuznets curve. 


\section{Figure 3}

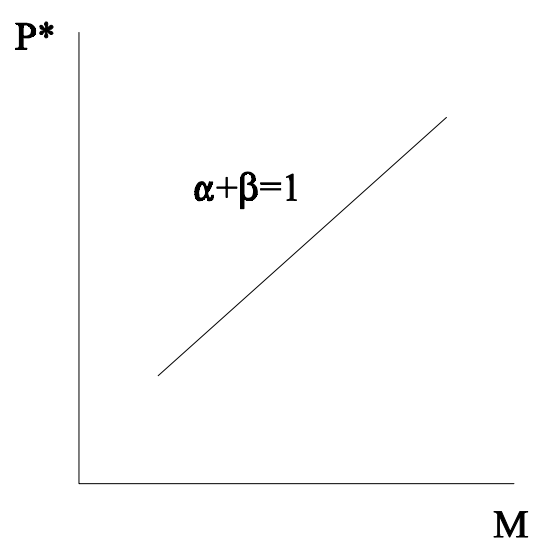

(a)

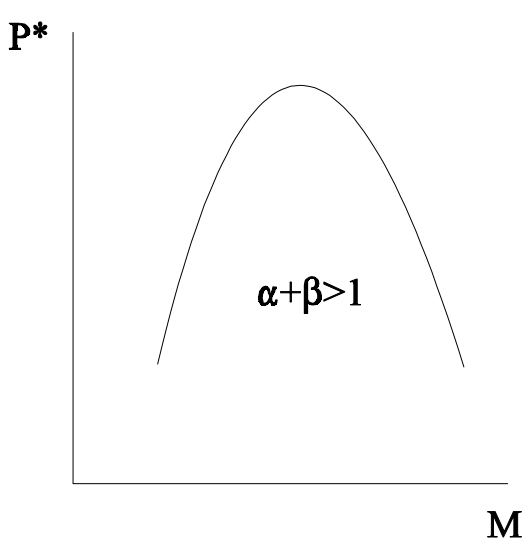

(b)

What shape does (6) have? When $\alpha+\beta=1$, effort spent abating pollution has constant returns to scale, and $\partial P^{*} / \partial M$ is constant, as in Figure 3a. However, if $\alpha+\beta>1$, abatement has increasing returns to scale, and $P^{*}(M)$ is concave as in Figure $3 \mathrm{~b}$. This is what has been described as an environmental Kuznets curve. ${ }^{2}$

The normative implication of this one-person model is that an inverse-U-shaped pollution-income path can be entirely consistent with Pareto-optimality. Because there is only one person, his optimum is by construction socially optimal. There are no market failures, and yet Crusoe's world gets dirtier with income at low levels, and cleaner at high levels.

So observing an inverse $\mathrm{U}$ is not sufficient evidence for a market failure. What about the converse? Might an observed inverse U be sufficient evidence that the market is inefficient? To examine this question, consider a multi-person version of the above model:

${ }^{2}$ For a more general version of this model, see Andreoni and Levinson (2001). 


$$
\begin{aligned}
U_{i} & =C_{i}-P, & & i=1 \ldots N, \\
P & =C-C^{\alpha} E^{\beta}, & & C=\sum_{i} C_{i}, E=\sum_{i} E_{i}, \\
M_{i} & =C_{i}+E_{i}, & & \alpha, \beta \in(0,1) .
\end{aligned}
$$

Suppose individuals, indexed $i=1 \ldots N$, take others' consumption and effort as given. Solving the first-order condition for consumer $i$ yields the best response function:

$$
C_{i}^{*}=\frac{\alpha}{\alpha+\beta} M_{i}+\left[\frac{\alpha}{\alpha+\beta} \sum_{j \neq i} M_{j}-\sum_{j \neq i} C_{j}\right] .
$$

If all individuals maximize utility this way, the symmetric Nash equilibrium is

$$
C_{i}^{*}=\frac{\alpha}{\alpha+\beta} M_{i} \quad \text { for all } i
$$

In this decentralized case, pollution follows the same path as in the one-person Robinson Crusoe example in equation (6) - the pollution-income path is concave and peaked when $\alpha+\beta>1$.

To examine the Pareto-efficiency of this outcome, compare this Nash equilibrium to the centrally planned optimum. The centralized solution maximizes the sum of utilities

$$
\max \sum_{i} U_{i}=\sum_{i} C_{i}-N P .
$$

Note that this aggregate utility function is identical to (3), where $C$ is replaced by $\sum \mathrm{C}_{i}$ and the marginal social disutility of pollution is $-N$ rather than -1 . This is just like the model in (3) except that when $N>1$, the disutility of pollution is greater. In the centralized solution, 


$$
C^{*}=\frac{\alpha}{\alpha+\beta} M+\frac{1-N}{N(\alpha+\beta)\left(C^{*}\right)^{\alpha-1}\left(M-C^{*}\right)^{\beta-1}}
$$

The second term of (11) is negative if $N>1$, so $C^{*}$ must be smaller than the Nash equilibrium $C$ in equation (9), and the corresponding level of pollution is lower.

The larger is $N$, the higher the marginal social cost of a unit of pollution, and the lower will be optimal consumption $C^{*}$. Though the optimal levels of $C^{*}$ and $P^{*}$ at any income change in response to changes in $N$, the implications for the inverse-U-shaped pollution-income path remain the same -- it is inverse-U-shaped so long as $\alpha+\beta>1$.

The normative conclusion must be that observing an inverse-U-shaped pollution-income path is neither necessary nor sufficient evidence that environmental policy is efficient, because it can be consistent with either efficient policies or market failures.

Figure 4 depicts the results of a simulation of this model, with particular parameters. The base case has one person $(\mathrm{N}=1)$, and $\alpha=\beta=0.8$. Optimal pollution, $P^{*}$, is plotted against income $M$, and the curve peaks at around $M=0.9$ and $P^{*}=0.17$. By contrast, examine the case with identical parameters but two agents $(N=2)$. Here the decentralized solution is identical to the base case, peaking when $M=0.9$ and $P=0.17$. But the centralized solution peaks at much lower pollution and income $\left(M=0.6\right.$ and $\left.P^{*}=0.019\right)$. Though the decentralized result is "selfcorrecting," it does so at excessively high income and pollution -- too little too late. With two agents, the marginal social damage from pollution is greater, and given returns to scale in abatement, more abatement and less pollution will be optimal. 
From the theory outlined in Table 2, we can see that inverse-U-shaped pollution-income paths can be generated in a wide variety of models. Some are Pareto-efficient, some are not. The conclusion must be that an inverse-U is neither necessary nor sufficient for Paretooptimality. However, most of the theoretical mechanics and assumptions in the literature are unnecessary to make this point. Figure 4 depicts two inverse-U-shaped pollution income paths. The top path is the decentralized result with two agents. The bottom path is the Pareto-optimal path for two agents. So the empirical observation is uninformative as to the efficiency or inefficiency of various countries' environmental policies.

\section{A Final Point: The Environmental Kuznets Curve Is Unrelated to the Environment}

The model outlined in the previous section generates an inverse-U-shaped pollutionincome curve for a simple Robinson Crusoe economy, with no externalities. The phenomenon, therefore, would seem to be unrelated to pollution, and would be present any time a market good is associated with an undesirable side effect that can be mitigated. Take, for example, the case of driving. The good -- transportation -- is associated with accident risk. But accident risk can be mitigated by purchasing cars with anti-lock brakes, side-impact air bags, and by proper vehicle maintenance, all of which cost resources that could be spent in other ways. If safety is a normal good, and the cost of vehicle safety improvements do not increase faster than the marginal utility of the associated safety, then we should expect accident risk to have an inverse-U-shaped relationship to household income.

Figure 5 uses data from the 1995 Nationwide Personal Transportation Survey and the 1995 Fatality Analysis Reporting System, both collected by U.S. Department of Transportation, 
to predict annual fatal accident risk by household income. The predictions are based solely on (a) make, model, and year of vehicle driven, and (b) how far it is driven. For each household income range (e.g. $\$ 45$ to $\$ 50$ thousand dollars), I estimate the ownership of each type of vehicle, and mileage. For each vehicle type, I estimate likelihood of a fatal accident, per mile driven. Multiplying this second term by the proportions for each household income class generates the likelihood of a fatal accident.

The shape of the accident-rate versus income plot in figure 5 is inverse-U-shaped for the same reasons the environmental Kuznets curve is inverse-U-shaped. Poor people either do not own cars, or do not drive them much. Rich people own cars and drive them, but own late-model, well-maintained vehicles with extra safety features. Middle-income people, who drive more miles in less-safe vehicles, suffer the highest risk. This relationship, the technological link between desirable goods and undesirable outcomes, is broader and more general than might be suggested by the term "Environmental" Kuznets curve.

\section{Conclusion}

Grossman and Krueger (1995), who sparked this literature, wrote in their abstract that most pollution problems appear to begin improving before countries' per capita incomes reach \$8000. This description of an inverse-U-shaped pollution-income pattern set off an empirical hunt for other inverse-U-shaped patterns, and a theoretical hunt for general theories of this pattern. Meanwhile, in the text of their paper is the less eye-catching conclusion that there is "no evidence that environmental quality deteriorates steadily with economic growth." Though unsurprising to economists, who can demonstrate the result using simple theory, this finding is 
useful in policy circles where environmental and economic issues are often seen solely as a tradeoff.

Based on this brief perusal of the literature to date, the conventional wisdom on the state of knowledge on economic growth and the environment can be summarized as follows.

Empirically, many researchers have used a variety of specifications to tease inverse-U-shaped pollution-income patterns out of noisy aggregate data, though skeptics have argued that these results are not replicable, and are sensitive to functional forms and specifications. Theoretically, inverse-U-shaped pollution-income paths can be the result of numerous causes, modeled in increasingly complex ways. In some cases, the inverse-U shape may be evidence for market failures. In other cases, the shape is consistent with efficient resource allocation.

The key insight therefore are that (a) pollution does not inevitably increase with growth, (b) inverse-U-shaped pollution-income paths are neither necessary nor sufficient evidence for market failures or efficiency, and (c) the inverse- $\mathrm{U}$ derives from a technological link between a desirable good and an undesirable side-effect, which is broader and more general than the environment.

All of these points can be made without most of the empirical and theoretical mechanics in the literature. To demonstrate the first point, all we need do is show that some pollutants have declined, even in countries growing rapidly. For the second point, all that is required is a static, one-good, model, in which both the centralized (efficient) and decentralized (inefficient) pollution-income relationships are inverse-U-shaped. For the third, a few extensions into other applications suffice. As this literature inevitably proliferates, these three points will be important to keep in mind. 


\section{References}

Arora, Seema and Timothy N. Cason. 1999. "Do Community Characteristics Influence Environmental Outcomes? Evidence From the Toxics Release Inventory" Southern Economic Journal 65, 691-716.

Andreoni, James, and Arik Levinson. 2001. "The Simple Analytics of the Environmental Kuznets Curve" Journal of Public Economics. Forthcoming.

Bartlett, Bruce. 1994. "The high cost of turning green" The Wall Street Journal September 14.

Beckerman, W. 1992. "Economic growth and the environment: Whose growth? Whose environment?" World Development 20 481-496.

Bradford, David F., Rebecca Schliechkert, Stephen H. Shore. 2000. "The Environmental Kuznets Curve: Exploring a Fresh Specification." NBER Working Paper \#8001.

Chaudhuri, Shubham and Alexander Pfaff. 1998a. "Household Income, Fuel Choice, and Indoor Air Quality: Microfoundations of an Environmental Kuznets Curve" mimeo, Columbia University Economics Department working paper.

Chaudhuri, Shubham and Alexander S.P. Pfaff. 1998b. "Household production, the bundling of services and degradation, and non-monotonic environmental Engle curves," Columbia University Economics Department working paper.

Cropper, M. and C. Griffiths. 1994. "The interaction of populations, growth and environmental quality" American Economic Review 84 250-254.

Ekins, P. 1997. "The Kuznets Curve for the Environment and Economic Growth: Examining the Evidence" Environment and Planning 29(5) 805-830.

Galeotti, Marzio and Alessandro Lanza. 1999. "Desperately Seeking (Environmental) Kuznets" mimeo, International Energy Agency, Paris.

Greenstone, Michael. 2001. University of Chicago. Working paper.

Grossman, G. and A. Krueger. 1995. "Economic growth and the environment" Quarterly Journal of Economics 110(2) 353-377.

Harbaugh, William, Arik Levinson, and David Wilson. 2000. "Reexamining the Empirical Evidence for an Environmental Kuznets Curve," NBER Working Paper \#7711, May. 
Hilton, F.G. Hank and Arik Levinson. 1998. "Factoring the Environmental Kuznets Curve: Evidence from Automotive Lead Emissions," Journal of Environmental Economics and Management, 35 126-141.

Holtz-Eakin, D. and T. Selden. 1995. "Stoking the fires? $\mathrm{CO}_{2}$ emissions and economic growth" Journal of Public Economics 57(1) 85-101.

Jaeger, William. 1998. "Growth and Environmental Resources: A Theoretical Basis for the U-shaped Environmental Path" mimeo, Williams College.

John, A. and R. Pecchenino. 1994. "An Overlapping Generations Model of Growth and the Environment" The Economic Journal 104 1393-1410.

John, A., R. Pecchenino, D. Schimmelpfennig, and S. Schreft. 1995. "Short-lived Agents and the Long-lived Environment" Journal of Public Economics 58 127-41.

Jones, Larry E. and Rodolfo E. Manuelli. 2000. "Endogenous Policy Choice: The Case of Pollution and Growth," Review of Economic Dynamics.

Kahn, Matthew E. 1998. "A Household Level Environmental Kuznets Curve" Economics Letters 59(2) 269-273.

Kelly, David. 1999. "On Kuznets Curves Arising from Stock Externalities," mimeo, University of Miami.

Kuznets, Simon. 1955. "Economic growth and income inequality" American Economic Review 45(1) $1-28$.

Millimet, Daniel L. and Thanasis Stengos. 1999. "A Semiparametric Approach to Modeling the Environmental Kuznets Curve Across US States" mimeo, Southern Methodist University.

Moomaw, William R. and Gregory C. Unruh. 1998. "Are Environmental Kuznets Curves Misleading Us?" Tufts University Working Paper.

Roberts, J. Timmons and Peter E. Grimes. 1997. "Carbon Intesity and Economic Development 1962-1991: A Brief Exploration of the Environmental Kuznets Curve" World Development 25, 191-198.

Selden Thomas M. and Daqing Song. 1994. "Environmental quality and development: Is there a Kuznets curve for air pollution emissions?" Journal of Environmental Economics and Management 27 147-162. 
Selden, Thomas M. and Daqing Song. 1995. "Neoclassical Growth, the J Curve for Abatement, and the Inverted U Curve for Pollution," Journal of Environmental Economics and Management 29(2), 162-68.

Shafik, N. and S. Bandyopadhyay. 1992. "Economic growth and environmental quality: Time series and cross-section evidence." World Bank Policy Research Working Paper \#WPS904. Washington, D.C.: The World Bank.

Stern, D. and M. Common. 1996. "Economic Growth and Environmental Degradation: The Environmental Kuznets Curve and Sustainable Development" World Development 24(7) 1151-1160.

Stern D. I. and M. S. Common. 2000. "Is there an environmental Kuznets curve for sulfur?" Journal of Environmental Economics and Management 40(2).

Stokey, Nancy L. 1998. "Are There Limits to Growth?" International Economic Review 39(1) 131.

Summers, R. and A. Heston. 1991. "The Penn World Table (Mark 5): An Expanded Set of International Comparisons, 1950-1988" Quarterly Journal of Economics 329-68.

Suri, Vivek and Duane Chapman. 1998. "Economic Growth, Trade and Energy: Implications For the Environmental Kuznets Curve" Ecological Economics 25(2) May 195-208.

Taskin, Fatma and Osman Zaim. 2000. "Searching for a Kuznets Curve in Environmental Efficiency using Kernel Estimation" Economics Letters 68, 217-223.

Torras, Mariano and James K. Boyce. 1998. "Income, inequality, and pollution: A Reassessment of the Environmental Kuznets Curve" Ecological Economics 25(2) May 147-160.

Wang, Pingo, Alok K. Bohara, Robert P. Berrens and Kishore Gawande. 1998. "A Risk-based Environmental Kuznets curve for US hazardous Waste Sites" Applied Economics Letters 5, 761-763.

World Bank. 1992. World Development Report 1992. New York: Oxford University Press. 


\section{Table 1. Selected empirical papers on the environmental Kuznets curve}

\begin{tabular}{|c|c|c|c|c|}
\hline Paper & Pollutants & Data & Specification & Findings \\
\hline $\begin{array}{l}\text { Grossman and } \\
\text { Krueger (1991) }\end{array}$ & $\begin{array}{l}\mathrm{SO}_{2}, \mathrm{TSP}, \text { water } \\
\text { quality. }\end{array}$ & $\begin{array}{l}\text { various countries, } \\
\text { years }\end{array}$ & $\begin{array}{l}\text { Cubic in logs, random } \\
\text { effects, with lagged GDP }\end{array}$ & $\begin{array}{l}\text { Most pollutants peak before GDP/capita reaches } \\
\$ 8000 \text {. }\end{array}$ \\
\hline $\begin{array}{l}\text { Shafik and } \\
\text { Bandyopadhyay } \\
(1994)\end{array}$ & $\begin{array}{l}\mathrm{SPM}, \mathrm{SO}_{2} \text {,fecal } \\
\text { coliforms in } \\
\text { rivers, sanitation, } \\
\text { municipal waste, } \\
\text { carbon } \\
\text { emissions, } \\
\text { deforestation }\end{array}$ & $\begin{array}{l}149 \text { countries } 1960- \\
1990\end{array}$ & $\begin{array}{l}\text { panel regression based } \\
\text { on OLS log linear, } \\
\text { quadratic, cubic }\end{array}$ & $\begin{array}{l}\text { Water and sanitation pollution peak earliest. Urban } \\
\text { air pollution peaks for middle income countries. }\end{array}$ \\
\hline $\begin{array}{l}\text { Sleden and Song } \\
\text { (1994) }\end{array}$ & $\begin{array}{l}\text { panel of } \\
\mathrm{NOxCOSPMSO}_{2}\end{array}$ & $\begin{array}{l}30 \text { countries, three } \\
\text { periods }(1973-1975 \\
1979-1981,1982- \\
1984)\end{array}$ & $\begin{array}{l}\text { pooled } x \text {-section, fixed } \\
\text { effects, random effects }\end{array}$ & $\begin{array}{l}\text { Substantial supposrt for the inverted-U hypthesis, } \\
\text { but with turning points at higher incomes. }\end{array}$ \\
\hline $\begin{array}{l}\text { Holtz-Eakin and } \\
\text { Selden (1995) }\end{array}$ & $\mathrm{CO} 2$ & $\begin{array}{l}\text { uneven panel of data } \\
\text { on } 130 \text { countries } \\
1951-1986\end{array}$ & $\begin{array}{l}\text { quadratic in levels and } \\
\text { natural logs }\end{array}$ & $\begin{array}{l}\text { Concave emissions-income path, but no peak } \\
\text { within reasonable range of incomes. }\end{array}$ \\
\hline $\begin{array}{l}\text { Roberts and } \\
\text { Grimes (1997) }\end{array}$ & $\mathrm{CO} 2$ & US for 1962-1991 & $\begin{array}{l}\text { OLS with linear and } \\
\text { curvilinear effects of level } \\
\text { of economic } \\
\text { development on } \mathrm{CO} 2 \\
\text { emissions }\end{array}$ & $\begin{array}{l}\text { Concavity of carbon emissions-income curve due } \\
\text { to a relatively small number of wealthy countries } \\
\text { becoming more efficient. No peak emissions at } \\
\text { reasonable income levels. }\end{array}$ \\
\hline $\begin{array}{l}\text { Hilton and } \\
\text { Levinson (1998) }\end{array}$ & $\begin{array}{l}\text { automotive lead } \\
\text { emissions }\end{array}$ & $\begin{array}{l}48 \text { countries. } \\
\text { Leaded gasoline } \\
\text { data from Octel }\end{array}$ & $\begin{array}{l}\text { quadratic in levels and } \\
\text { logs, splines }\end{array}$ & $\begin{array}{l}\text { Predicted peak lead emissions is sensitive to } \\
\text { functional form and time period. Decomposes } \\
\text { scale and technique effects. }\end{array}$ \\
\hline
\end{tabular}

(continued) 
(continued from previous page)

\begin{tabular}{|c|c|c|c|c|}
\hline Kahn (1998) & $\begin{array}{l}\text { Automotive } \\
\text { hydrocarbon } \\
\text { emissions }\end{array}$ & 1993 California, USA & OLS & $\begin{array}{l}\text { Finds inverted-U-shaped emissions/income relation } \\
\text { peaking at } \$ 25.000 \text {. }\end{array}$ \\
\hline $\begin{array}{l}\text { Wang, et al. } \\
\text { (1998) }\end{array}$ & $\begin{array}{l}\text { Exposure to toxic } \\
\text { waste. }\end{array}$ & $\begin{array}{l}\text { Cross section of US } \\
\text { counties in } 1990 .\end{array}$ & Tobit estimation & $\begin{array}{l}\text { Inverted-U-shaped relationship between toxic } \\
\text { waste and county income. }\end{array}$ \\
\hline $\begin{array}{l}\text { Chaudhuri and } \\
\text { Pfaff (1998) }\end{array}$ & $\begin{array}{l}\text { Indoor air } \\
\text { pollution }\end{array}$ & $\begin{array}{l}\text { Household level data } \\
\text { in Pakiston }\end{array}$ & $\begin{array}{l}\text { Tobit estimates of fuel } \\
\text { use, translated into air } \\
\text { quality. }\end{array}$ & $\begin{array}{l}\text { Inverted-U-shaped relationship between household } \\
\text { income and indoor air quality. }\end{array}$ \\
\hline $\begin{array}{l}\text { Millimet and } \\
\text { Stengos (1999) }\end{array}$ & $\begin{array}{l}\text { Toxic releases } \\
\text { from TRI. }\end{array}$ & US states1988-1996 & $\begin{array}{l}\text { semiparametric partially } \\
\text { linear log }\end{array}$ & $\begin{array}{l}\text { N-shaped path, turning up at high incomes } \\
(\$ 30,000 \text { per capita). }\end{array}$ \\
\hline $\begin{array}{l}\text { Arora and Cason } \\
\text { (1999) }\end{array}$ & $\begin{array}{l}\text { Toxic releases } \\
\text { from TRI. }\end{array}$ & $\begin{array}{l}1993 \text { cross section of } \\
30,000 \text { zip codes. }\end{array}$ & $\begin{array}{l}\text { 2-stage maximum } \\
\text { likelihood sample } \\
\text { selection model where } \\
\text { the first stage estimates } \\
\text { a probit model. }\end{array}$ & $\begin{array}{l}\text { Variables that proxy for collective action } \\
\text { significantly reduce local releases. }\end{array}$ \\
\hline $\begin{array}{l}\text { Harbaugh et al. } \\
\text { (2000) }\end{array}$ & $\mathrm{SO}_{2}, \mathrm{TSP}$ & $\begin{array}{l}\text { various years and } \\
\text { countries }\end{array}$ & $\begin{array}{l}\text { Fixed effects, panel, with } \\
\text { polynomials in GDP and } \\
\text { lagged GDP. }\end{array}$ & $\begin{array}{l}\text { Grossman and Krueger's (1995) findings are } \\
\text { sensitive to countries studied, years covered, } \\
\text { functional form, and econometric, specification. } \\
\text { Confidence bands around the pollution-income } \\
\text { path render its shape uncertain. }\end{array}$ \\
\hline $\begin{array}{l}\text { Taskin and Zaim } \\
(2000)\end{array}$ & $\begin{array}{l}\mathrm{CO} 2 \text { emissions } \\
\text { (millions of tons) }\end{array}$ & $\begin{array}{l}\text { cross-section data on } \\
52 \text { countries 1975- } \\
1990\end{array}$ & $\begin{array}{l}\text { nonparametric kernel } \\
\text { regression technique }\end{array}$ & $\begin{array}{l}\text { Improved environmental quality at the initial phases } \\
\text { of growth (up to GDP/capita of } \$ 5000 \text { ), followed by } \\
\text { a phase of deterioration (up to } \$ 12000 \text { ), and then } \\
\text { improvement again. }\end{array}$ \\
\hline $\begin{array}{l}\text { Bradford, et al. } \\
(2000)\end{array}$ & $\begin{array}{l}13 \text { different air } \\
\text { and water } \\
\text { pollutants }\end{array}$ & $\begin{array}{l}\text { various years and } \\
\text { countries }\end{array}$ & $\begin{array}{l}\text { New variant on cubic } \\
\text { function with fixed } \\
\text { effects. }\end{array}$ & $\begin{array}{l}\text { Similar to Grossman and Krueger: some pollutants } \\
\text { exhibit inverse-U's, others do not. }\end{array}$ \\
\hline
\end{tabular}




\section{Table 2. Theoretical models of growth and the environment}

\begin{tabular}{|c|c|c|c|}
\hline Paper & Model & Cause of non-monotonicity & Results \\
\hline John and Pecchnino (1994) & $\begin{array}{l}\text { Overlapping generations } \\
\text { model. Environmental quality } \\
\text { is a stock resource that } \\
\text { degrades over time unless } \\
\text { maintained by investment in } \\
\text { the environment. }\end{array}$ & $\begin{array}{l}\text { An economy that begins at the } \\
\text { corner solution of zero } \\
\text { environmental investment degrades } \\
\text { its environment with economic } \\
\text { growth until positive environmental } \\
\text { investment is desired. Then } \\
\text { environmental quality begins } \\
\text { improving. }\end{array}$ & $\begin{array}{l}\text { Inverse-V shaped, peaking when } \\
\text { the dynamic equilibrium switches } \\
\text { from a corner solution of zero } \\
\text { environmental investment to an } \\
\text { interior optimum with positive } \\
\text { investment. }\end{array}$ \\
\hline \multicolumn{4}{|l|}{ Selden and Song (1994) } \\
\hline \multicolumn{4}{|l|}{ Jaeger (1998) } \\
\hline Stokey (1998) & $\begin{array}{l}\text { Static model, choice of } \\
\text { production technologies with } \\
\text { varying degrees of pollution. }\end{array}$ & $\begin{array}{l}\text { Blow a threshold level of economic } \\
\text { activity, only the dirtiest technology } \\
\text { can be used. With economic } \\
\text { growth, pollution increases linearly } \\
\text { with income until the threshold is } \\
\text { passed and cleaner technologies } \\
\text { can be used. }\end{array}$ & $\begin{array}{l}\text { Inverse-V-shaped pollution- } \\
\text { income path, with a sharp peak } \\
\text { at the point where a continuum of } \\
\text { cleaner technologies becomes } \\
\text { available. }\end{array}$ \\
\hline \multicolumn{4}{|l|}{ Kelly (1999) } \\
\hline Jones and Manuelli (2000) & $\begin{array}{l}\text { Overlapping generations } \\
\text { model, with endogenous } \\
\text { formation of political } \\
\text { institution. }\end{array}$ & $\begin{array}{l}\text { Economy needs threshold income } \\
\text { to establish institutions for correcting } \\
\text { externalities. }\end{array}$ & $\begin{array}{l}\text { Monotonic increasing pollution, } \\
\text { inverted-U, or "sideways mirrored } \\
\text { S" }\end{array}$ \\
\hline Andreoni and Levinson (2001) & $\begin{array}{l}\text { Robinson Crusoe model } \\
\text { (static, one good, one person, } \\
\text { one period) }\end{array}$ & $\begin{array}{l}\text { Returns to scale in pollution } \\
\text { abatement technology. }\end{array}$ & $\begin{array}{l}\text { Pollution increases or decreases } \\
\text { with income. }\end{array}$ \\
\hline
\end{tabular}




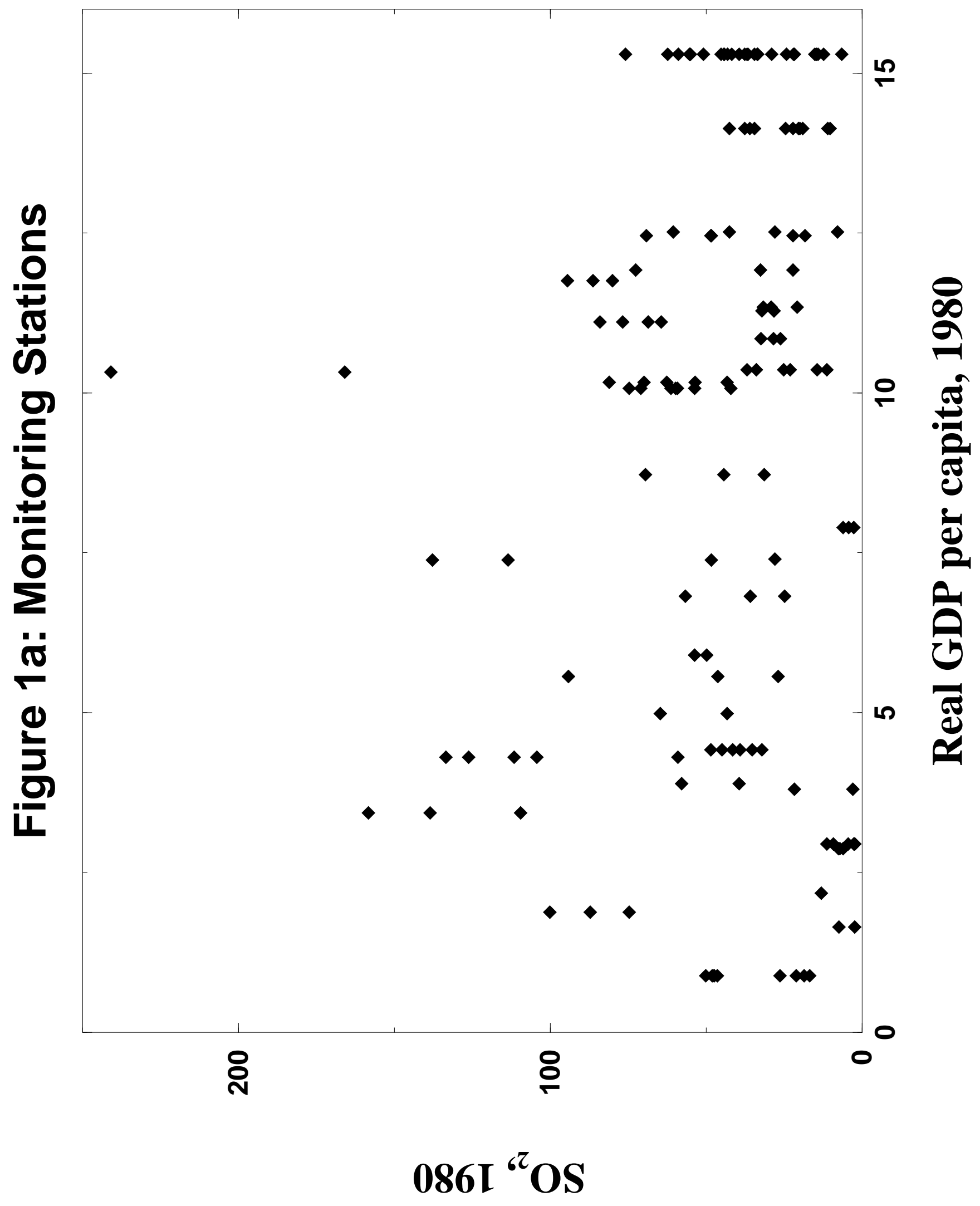




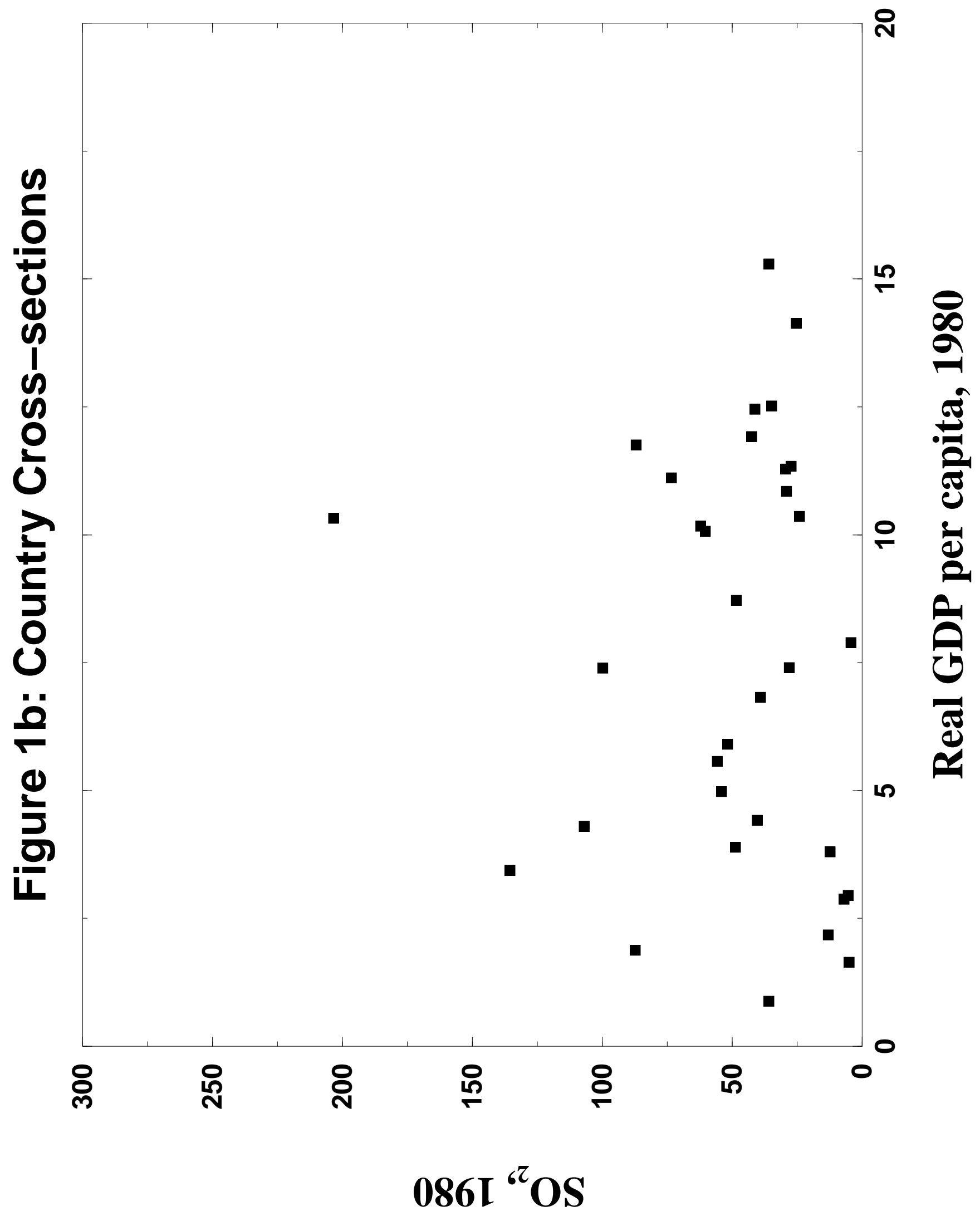




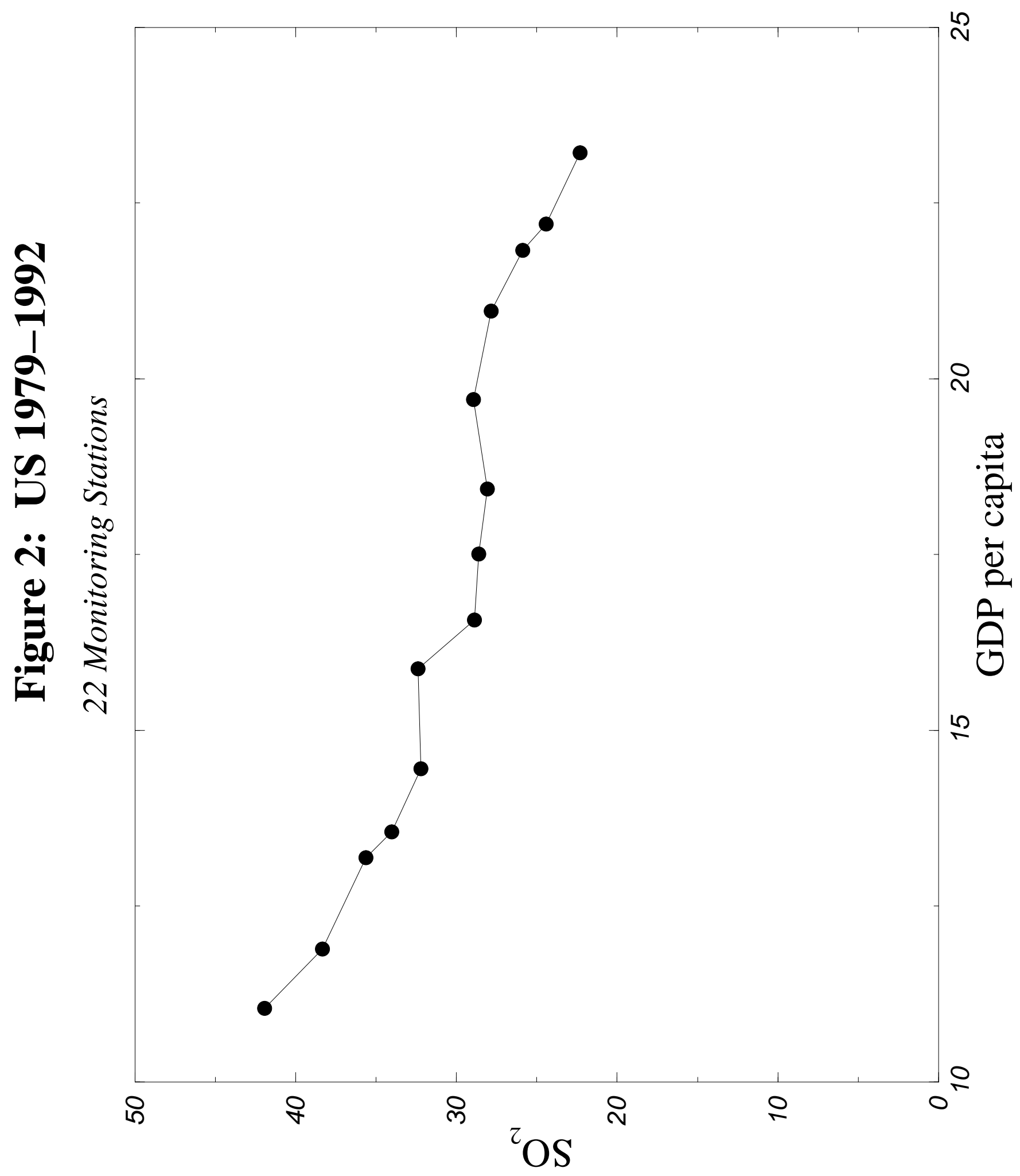




\section{Figure 4. Pollution-income curves}

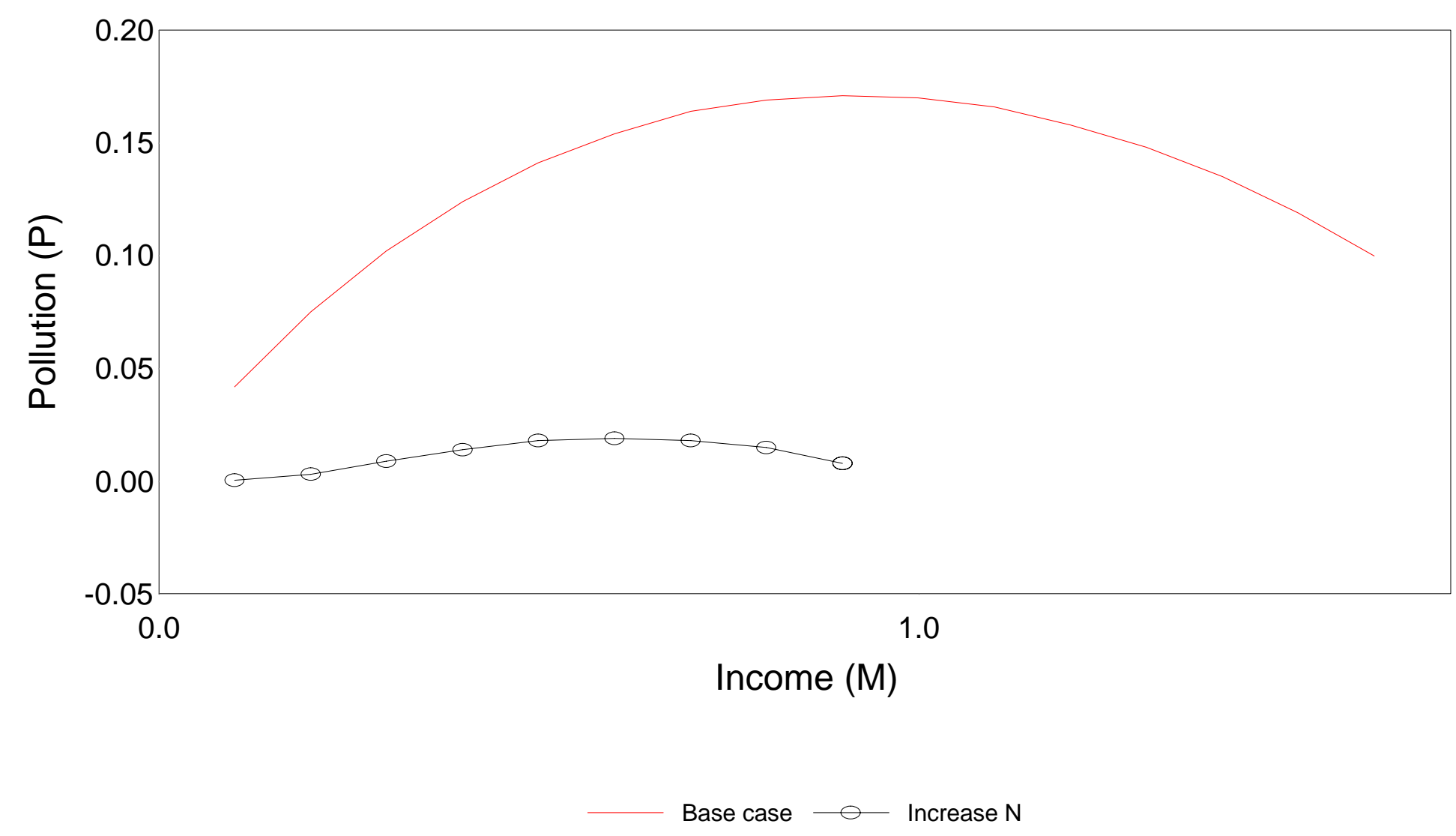

Note: For the base case scenario, N=1, and alpha=beta=0.8. For the "Increase N" scenario, N=2. 


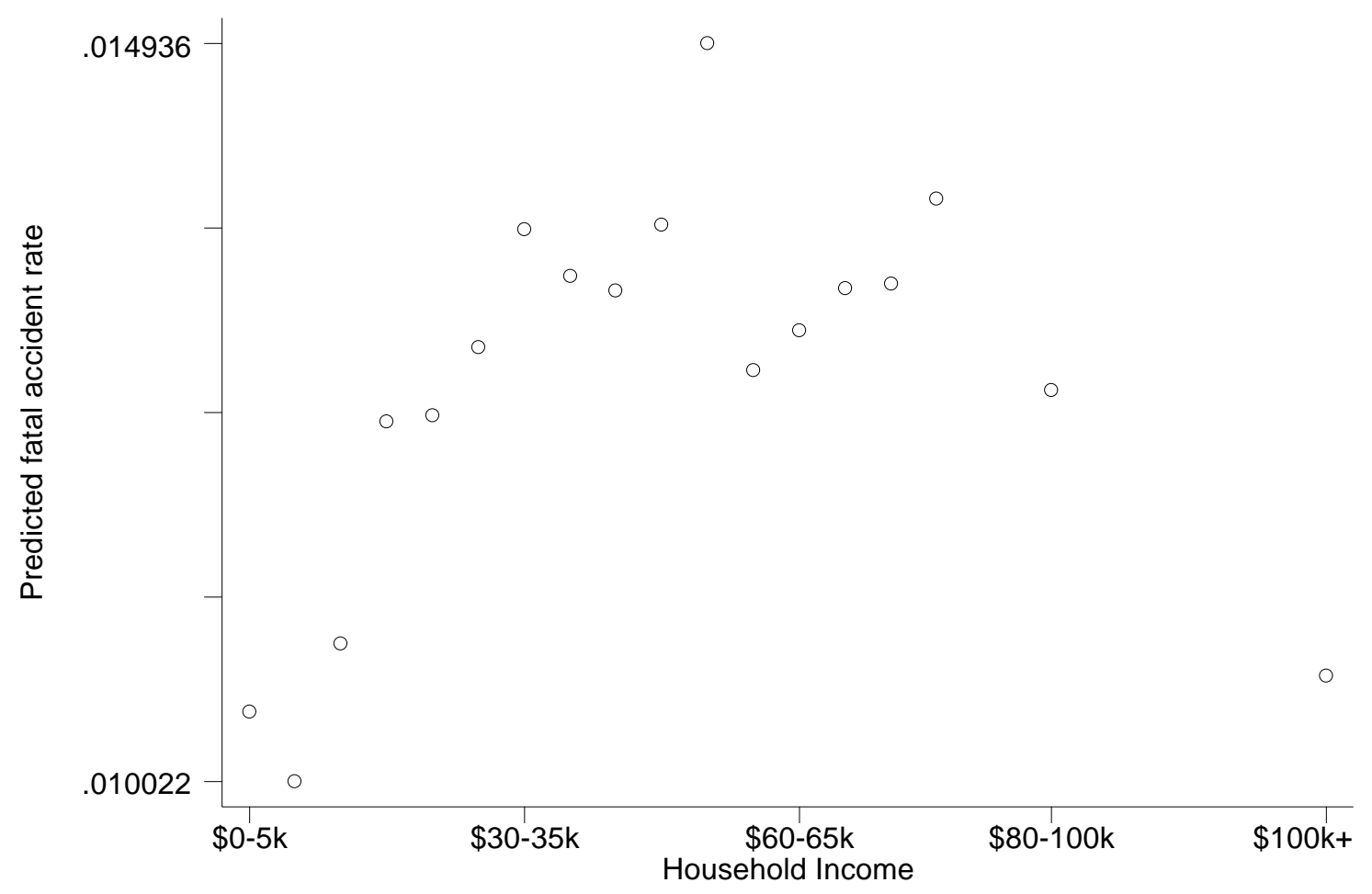

